\title{
Structural Characterization of Bauxite Red Mud to Utilization in Ceramic Wall/Roofing Tile: Effect of Temperature on Mechanical Properties and Physic-Chemical Stability
}

\author{
Ahmat Tom1, Paul Nestor Djomou Djonga2* ${ }^{2}$, Cornelius Tsamo3 ${ }^{3}$, Hambate Gomdje Valery4, \\ Joshiane Azangueu, ${ }^{4}$, Sandrine Kamdoum Noukelag 5
}

${ }^{1}$ Department of Energy Engineering, University Institute of Technology, University of Ngaoundere, Ngaoundere, Cameroon ${ }^{2}$ Department of Chemistry, Faculty of Science, University of Maroua, Maroua, Cameroon

${ }^{3}$ Department of Chemistry, Higher Teachers' Training College, University of Maroua, Maroua, Cameroon

${ }^{4}$ Departement of Textile and Leather Engineering, National Advanced School of Engineering of Maroua, University of Maroua, Maroua, Cameroon

${ }^{5}$ Department of Physics and Astronomy, University of the Western Cape, Cape Town, South Africa

Email: *djomoupaul@gmail.com

How to cite this paper: Tom, A., Djonga, P.N.D., Tsamo, C., Valery, H.G., Azangueu, J. and Noukelag, S.K. (2022) Structural Characterization of Bauxite Red Mud to Utilization in Ceramic Wall/Roofing Tile: Effect of Temperature on Mechanical Properties and Physic-Chemical Stability. Advances in Materials Physics and Chemistry, 12, 1-18. https://doi.org/10.4236/ampc.2022.121001

Received: May 24, 2021

Accepted: January 28, 2022

Published: January 31, 2022

Copyright $\odot 2022$ by author(s) and Scientific Research Publishing Inc. This work is licensed under the Creative Commons Attribution International License (CC BY 4.0).

http://creativecommons.org/licenses/by/4.0/ (c) (i) Open Access

\begin{abstract}
This present research work is on the characterization of bauxite red mud (waste material) from Ngaoundal for the manufacture of ceramic products. After the extraction process, the raw material was characterized using Scanning Electron Microscopy (SEM). Morphology, mineral phases and chemical composition were determined by using energy-dispersive X-ray (EDX) analysis, X-ray diffractometer (XRD), X-ray fluorescence (XRF). Differential Scanning Calorimetry and Thermal Gravimetric Analysis (DSC-TGA), Infra-Red (IR), Particle size (PS) were also used. Results of red mud analysis show that major oxides were $\mathrm{Fe}_{2} \mathrm{O}_{3}$ (37.21\%), $\mathrm{Al}_{2} \mathrm{O}_{3}$ (19.6\%), $\mathrm{SiO}_{2}$ (7.68\%), $\mathrm{TiO}_{2}(1.07 \%$ ), $\mathrm{Na}_{2} \mathrm{O}$ (4.71\%), and $\mathrm{CaO}(2.75 \%)$. These last oxides require low temperature to melt and act as binders which link particles of red mud during the sintering process. Presence of alkaline oxides is an appeal to reduce energy consumption during ceramic manufacture process and to protect our environment for sustainable development. Physical and mechanical properties of fired red mud showed that the firing shrinkage, bulk density, and flexural strength increase with firing temperature. Porosity and water absorption had the same pattern and they decreased with the increase of temperature. Chemical stability reveals that $10 \%$ material loss is obtained after 7 days of treatment under acid-base conditions.
\end{abstract}




\section{Keywords}

Bauxite, Red Mud, Characterization, Ceramics Wall Tile, Firing, Mechanical Properties

\section{Introduction}

Red mud is a highly alkaline solid waste produced from the alumina refinery plants. Generally, red mud comes out from the Bayer process or sintering process of alumina production. It is in from of slurry with high amount of sodium aluminates [1] [2]. Every year, more than 300 million tons of red mud is producing from the alumina industries in worldwide. The disposal of large quantities of red mud is very difficult and it leads to land, air and water pollution [1] [3]. Because it has high alkaline nature and it contains many hazardous substances like metals and radioactive elements [1] [4] [5] [6]. Chava V. et al. show that the production of 1 tonnes of alumina generated $1-1.5$ tonnes of red mud. Due to the alkaline nature and the chemical and mineralogical species present in red mud, this solid waste causes a significant impact on the environment and proper disposal of waste red mud presents a huge challenge where alumina industries are installed. The disposal cost is high, accounting for about $5 \%$ of alumina production [7] [8] [9]. Up to now, red mud has found limited applications in brick, glass, aerated concrete block, road base material, filling material in mining and plastic, as adsorbent to adsorb heavy metal ions and non-metallic ions from wastewater and soil and $\mathrm{SO}_{2}$ in the waste gas [7] [8] [10]. Unfortunately, none of these applications has been economically applied on an industrial scale [8]. There is not yet an economic way or an application of plant scale to utilize this red mud. Many studies have been said about the possibility of using the red mud as a cheap source of raw material for the manufacture of low-cost ceramic products [11] [12]. From earlier researches it was seen that this residue contains several oxides which can form a glassy phase after during processing. Because of the environmental impact of bauxite residue and its enormous volume through the environment, its treatment to change the alkalinity is an extremely urgent issue with the aim of converting the harmful red mud to useful products for different applications [13]. This will produce significant benefits in terms of environment and economics by reducing land fill volume, contamination of soil and ground water, and release of land for alternative uses. Currently, most red mud produced from alumina plants is disposed in landfills or dumped at sea. The cost of disposal is very high, constituting for approximately $5 \%$ of alumina production. Hence the question arises what to do with these large volumes of red mud with high polluting character. Because it contains compounds of $\mathrm{Na}, \mathrm{CA}, \mathrm{Si}$ and $\mathrm{K}$, it can act as fluxing agent and so could be of particular importance for use in the production of bricks, roofing tiles, rustic floor and wall tiles [14]. Moreover, it can be used to produce valued materials in ce- 
ramic manufacture and for other applications and thus saving natural resources [14] [15]. The objectives of the present work were to investigate the potential of red mud in ceramic tiles, through the preparation of test specimens from the red mud used as raw-materials. Mechanical Properties related to the sintering process such as the apparent density, water absorption, linear shrinkage, flexural strength were also characterized and the chemical resistance test were also evaluated.

\section{Materials and Experimental Methods}

\section{Bauxite Potentials of Study Area}

It is estimated that Cameroon has the $6^{\text {th }}$ world bauxite reserves. With approximately 1.8 billion tons from which 1 billion tons are estimated for the two groups of deposits situated in the Minim-Martap and Ngaoundal. These 1.8 billion tons seems to be underestimated, since there are many non-explored bauxite indices in Cameroon as indicated by the SABAP exploration license [13] [14] [15] and the recent geological map of Cameroon (Figure 1).

\subsection{Preparation of Sample}

Red mud used for this study was produced in our laboratory from bauxite collected at Mount Ngaoundal (6 $6^{\circ} 27^{\prime} 55^{\prime \prime}-$ North, $13^{\circ} 16^{\prime} 16^{\prime \prime}$ East). The method employed used in the extraction of red mud from bauxite was that used by Tsamo et al., [14] adapted from the Bayer process. In which $20 \mathrm{~g}$ of finely crushed and grind bauxite (powder particles of diameter $<75 \mu \mathrm{m}$ ) were mix with $40 \mathrm{ml}$ solution of $3 \mathrm{M} \mathrm{NaOH}$ in an Erlenmeyer flask and stirred (300 tr/min) for $10 \mathrm{mi}-$ nutes. The reaction mixture was then, heated at $80^{\circ} \mathrm{C}$ for 20 minutes, allowed to cool down and filtered. Red mud was collected on the filter paper and drying at room temperature before processing [14].

\subsection{Characterization Techniques}

Due to the fact that Cameroon is not yet processing its bauxite, the bauxite collected at Ngaoundal $\left(6^{\circ} 27^{\prime} 55^{\prime \prime} \mathrm{N}, 13^{\circ} 16^{\prime} 16^{\prime \prime} \mathrm{E}\right)$ was used in producing the red mud in the laboratory as described in our previous studies [11] [12]. Sampled bauxite was washed with distilled water, crushed in porcelain mortar and dried at $105^{\circ} \mathrm{C}$

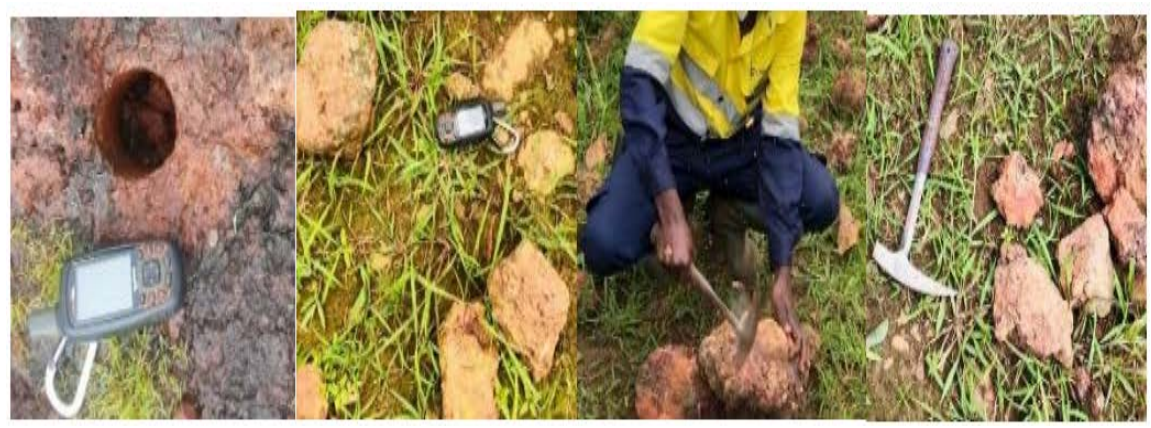

Figure 1. Bauxite and sampling area. 
for $24 \mathrm{~h}$ using a HERAEUS type VT $5042 \mathrm{EK}$ oven. The dried particles were then sieved to obtain particle size of $75 \mu \mathrm{m}$ used for characterization studies and ceramic production. The chemical composition of red mud and waste glass was determined using the XRF (AXIOS PANalytical, Dy 1680) while the surface functional groups were determined by FTIR (Fourier transform infrared spectroscopy Spectrophotometer, (Bruker Make), Model: ALPHA-P). The presence of mineral compounds in waste glass and red mud, was determined by XRD using a Philips X'Pert PRO diffractometer. The different diffraction peaks recorded were compared with those of similar samples reported in literature for identification. The DSC-TGA technique (SDT Q600 V20.9 Build 20) was used to identify the different phase transformations involved in waste glass and red mud samples with heating while SEM was used to determine the surface morphology of the solid materials [16].

\subsection{Formulation and Shaping}

Plastic pastes prepare from red mud material powder were homogeneously mixed with water at $12 \%(\mathrm{w} / \mathrm{w})$. After crushed and sieved using a $75 \mu \mathrm{m}$ sieve, the mixture was produced by extrusion in a parallelepiped $(82 \mathrm{~mm} \times 42 \mathrm{~mm} \times 9$ $\mathrm{mm}$ ) using a uniaxial pressing techniques at 10bars. Specimens were dried for 48 $\mathrm{h}$ at room temperature in the laboratory, oven-dried at $110^{\circ} \mathrm{C}$ for $24 \mathrm{~h}$, then fired in a kiln (Nabertherm, model $\mathrm{LH} 60 / 40$ ) at different temperature $800^{\circ} \mathrm{C}, 900^{\circ} \mathrm{C}$ and $1000^{\circ} \mathrm{C}$. For firing temperature up to $500^{\circ} \mathrm{C}$ the heating rate was set to $2.5^{\circ} \mathrm{C} / \mathrm{min}$. Once the desired temperature was reached, the sample was left at constant temperature for 2 hours and then heated at a rate of $5^{\circ} \mathrm{C} / \mathrm{min}$ up to the selected firing temperature where it was left for 2 hours before cooling down to room temperature [16] [17].

\subsection{Testing Method for the Physical and Mechanical Properties}

Several physical properties of the fired red mud can be determined: linear shrinkage, water absorption, apparent porosity, bulk density, apparent density, and loss on ignition. In this research, only the first four properties were considered.

The properties of the specimens obtained from sintering at the four temperatures with varying composition of glass were evaluated. The loss of mass due to drying at $110^{\circ} \mathrm{C}$ and firing at different temperatures was determined using ASTM-C326 standard [13] whereas the determination of the linear shrinkage was done by studying the variation of the mean length of spots recorded on the parallelepipeds between drying at $110^{\circ} \mathrm{C}$ and firing at different temperatures as described in ASTM-C326 standard [13]. Water absorption was carried out on cylindrical fired test specimens according to ASTM-C373 standard [14] where ceramic samples were weighed and immersed in a beaker containing distilled water and the ensemble boiled for $2 \mathrm{~h}$, and then allowed to cool for $24 \mathrm{~h}$ at room temperature. The specimens were then wiped with a paper towel and weighed. The flexural strength, determination was done according to ASTM-C 674 stan- 
dard [15] in which, the parallelepiped ceramic was placed on two cylindrical supports and horizontal portion fixed on a basement of vertical movement. A third motionless cylinder was placed above, parallel and symmetrical to the previous one. The basement that carries both cylinders has an average ascent of 3 $\mathrm{mm} / \mathrm{min}$ to reach breaking point. The dynamometer then indicates the force exerted to break the specimen which is then used to calculate the mechanical resistance to bending. Apparent porosity, bulk density and porosity were determined by Archimedes' Principle using the ASTM-C373 standard [14]. For the specimen's resistance to acid and base corrosion test, sulphuric acid $(\mathrm{pH}=1.68)$ and soda solution ( $\mathrm{pH}=13.24)$ were used (NEN-7375 standard) [16]. Samples were dried again for $24 \mathrm{~h}$ at $105^{\circ} \mathrm{C}$, and then weighted masses of the respective samples immersed in different $500 \mathrm{~mL}$ beakers containing acid or base solutions for 30 days, after which the samples were withdrawn and carefully wiped with dry tissue, dried again for $24 \mathrm{~h}$ at $105^{\circ} \mathrm{C}$ in the oven and weighed to get the final mass. The difference between this final mass and the initial mass of sample before treatment with acid or base gives the mass loss due to acid or base corrosion.

\section{Results and Discussion}

\subsection{Chemical Composition of the Powders}

Chemical composition of the red mud is given in Table 1 . The majority of the used powder consists of $\mathrm{SiO}_{2}, \mathrm{Al}_{2} \mathrm{O}$ and $\mathrm{Fe}_{2} \mathrm{O}_{3}$. These elements are of $64.49 \%$ for red mud material. These elements are fundamental for ceramic study. Red mud has $20.26 \%$ of loss on ignition. This lost can be justify by organic matter present in the material and some chemical reaction that occur during the processing. The types of elements present and the trends in content are similar to those reported by other authors [14] [18] [19] [20].

It is observed that $\mathrm{Fe}_{2} \mathrm{O}_{3}, \mathrm{~A}_{12} \mathrm{O}_{3}, \mathrm{SiO}_{2}, \mathrm{Na}_{2} \mathrm{O}, \mathrm{CaO}$ and $\mathrm{TiO}_{2}$ are major components of red mud. The high amount of $\mathrm{Na}_{2} \mathrm{O}+\mathrm{K}_{2} \mathrm{O}(4.77 \%)$ and $\mathrm{CaO}+\mathrm{MgO}$ $(2.83 \%)$, oxides which act as fluxes can easily facilitate the liquid phase formation during the firing stage of the ceramic [1].

The gaseous components constituted by carbon and $\mathrm{Fe}_{2} \mathrm{O}_{3}$ content, which can generate gases and bloat the ceramic bodies in the firing process. Finally the third group is fluxes constituted of alkali metal oxide and alkaline earth metal such as $\mathrm{CaO}, \mathrm{Na}_{2} \mathrm{O}, \mathrm{K}_{2} \mathrm{O}$ and $\mathrm{MgO}$, which help in lowering down the melting point [21] [22] [23].

The presence of $\mathrm{Al}_{2} \mathrm{O}_{3}$ and $\mathrm{SiO}_{2}$ is responsible for the good mechanical behaviour, shrinkage of a sample and $\mathrm{Fe}_{2} \mathrm{O}_{3}$ in constitution determines the colour of

Table 1. Chemical composition of the Red mud determined by XRF.

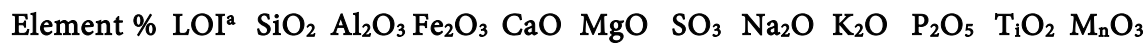

$\begin{array}{llllllllllll}\text { Red mud \% } 20.26 & 7.68 & 19.6 & 37.21 & 2.75 & 0.08 & 0.08 & 4.71 & 0.06 & 0.12 & 1.07 & 0.09\end{array}$

${ }^{a}$ Loss on ignition. 
the sample after firing. It is basically characterized by high amount of $\mathrm{SiO}_{2}$ and $\mathrm{Al}_{2} \mathrm{O}_{3}$. Raw materials present low amount of $\mathrm{SiO}_{2}$ and considerably amount of $\mathrm{Al}_{2} \mathrm{O}_{3}$. Quantity of earth-alkaline oxide $(\mathrm{CaO}$ and $\mathrm{MgO})$ that are auxiliary fluxes also is low, indicating that the studied raw materials during firing can formed a pore due to the loss of $\mathrm{CO}_{2}$. The chemical composition of red mud sample contain $\left(\mathrm{SiO}_{2}+\mathrm{Al}_{2} \mathrm{O}_{3}+\mathrm{Fe}_{2} \mathrm{O}_{3}\right)$ is high values $(64.49 \%)$, it's indicative is suitable to make quality ceramic product. These results agree with the literature [21] [22] [23] [24].

\subsection{IR Spectrum}

The IR spectrum of Bauxite red mud is divided into three absorption domains (Figure 2). The first domain consists of four absorption bands: 3653; 3735; 3648; $3335 \mathrm{~cm}^{-1}$ which are characteristic of the vibration of the $\mathrm{OH}$ bonds of the hydroxyl group of the gibbsite [25], basic mineral of the bauxite. This confirms the results shown by the DRX and DSC/ATG. The second domain consists of three absorption bands around 1060; 966 and $913 \mathrm{~cm}^{-1}$. These absorption bands correspond to the different modes of deformation vibration of the $\mathrm{OH}$ bond of the water molecule [26]. The band around $1500 \mathrm{~cm}^{-1}$ is characteristic of the valence vibration of the $\mathrm{C}=\mathrm{O}$ bond [27], whereas those between 1300 to $1400 \mathrm{~cm}^{-1}$ correspond to the vibration of the Si-O bond [28]. The peak around 913 corresponds to the vibration of the Si-O bond [29]. The spades around 843, 799 correspond to the Fe-OH group [30]. IR data confirms the results of XRD and XRF. We can conclude that red mud is well crystalized.

\subsection{Ramann Spectra}

Two very characteristic vibrations of gibbsite could be identified in the range from $100-700 \mathrm{~cm}^{-1}$ at $300 \mathrm{~cm}^{-1}, 480 \mathrm{~cm}^{-1}$, assigned to Al-O-Al deformation [25] [26]. Anatase even as a minor phase is an excellent scatter, and therefore Ramann Spectroscopy has remarkably low detection limit for anatase in red mud, as has been already started for kaolin [27]. Although band superposition compromises the diagnostic feature of the band at around $100 \mathrm{~cm}^{-1}$. It can still be used, as the overlapping gibbsite vibrations of lower intensity and fairly intense

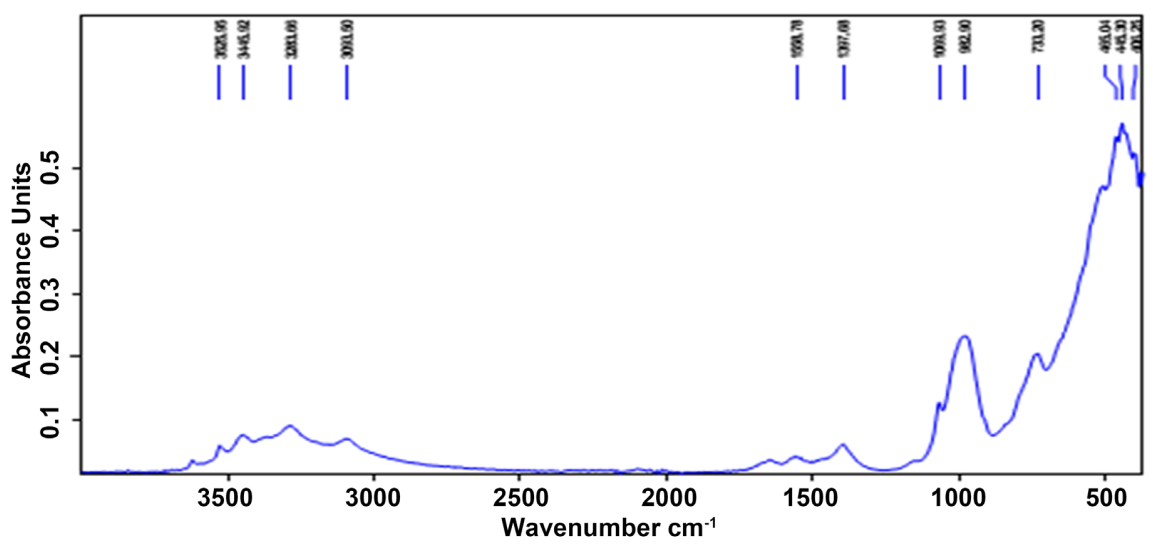

Figure 2. IR curve of red mud of Ngaoundal bauxite. 
kaolinite vibrations are displaced to lower wave number [28]. The only exclusive anatase band, however is the one at $675 \mathrm{~cm}^{-1}$ and its intensity might be below detection limits. From a mineral processing point of view, the identification and proportion of the iron oxides/hydroxides is the most important. Goethite and hematite use to be the minerals and hematite can easily be targeted by its diagnostic vibrations at $496 \mathrm{~cm}^{-1}$ [29]. Quartz, usually a common mineral in bauxites, has not been identified in our sample by its very characteristic band at $464 \mathrm{~cm}^{-1}$ [30]. Ramann, however is not able to detect as this configuration is limited $1200 \mathrm{~cm}^{-1}$ out of range of kaolinite's only exclusive vibration, at $3688 \mathrm{~cm}^{-1}$ (Figure 3).

\subsection{X-Ray-Diffraction}

The XRD pattern of red mud is given by Figure 4 and it is seen to contain the minerals: Anatase $\left(\mathrm{TiO}_{2}\right)$; Hematite $\left(\mathrm{Fe}_{2} \mathrm{O}_{3}\right)$; Diaspore (AlO (OH)); Gibbsite $\left(\mathrm{Al}(\mathrm{OH})_{3}\right.$; quartz $\left(\mathrm{SiO}_{2}\right)$; calcite $\left(\mathrm{CaCO}_{3}\right)$; Goethite $(\mathrm{FeO}(\mathrm{OH}))$; Albite $(\mathrm{NaAl}-$ $\left.\mathrm{Si}_{3} \mathrm{O}_{8}\right)$; Orthose $\left(\mathrm{KAlSi}_{3} \mathrm{O}_{8}\right)$; and Bohemite. As reported in literature, it can be seen that this red mud is dominated by iron minerals. The presence of quartz, orthose and albite silica minerals and alumina minerals confirm the XRF results. The XRD results show the variable contribution of red mud in the glassy phase, the gas components and fluxes of fired ceramics The XRD results show the variable contribution of red mud in the glassy phase, the gaseous components and fluxes of fired ceramics [13] [14].

\subsection{Analysis}

The Bauxite DSC thermogram (Figure 5) shows the following two thermal phenomena:

- An endothermic peak whose maximum is at $282^{\circ} \mathrm{C}$ and which corresponds to the departure of the free water contained in the red bauxite sludge which corresponds to the dehydroxylation of gibbsite [31] according to the equation:

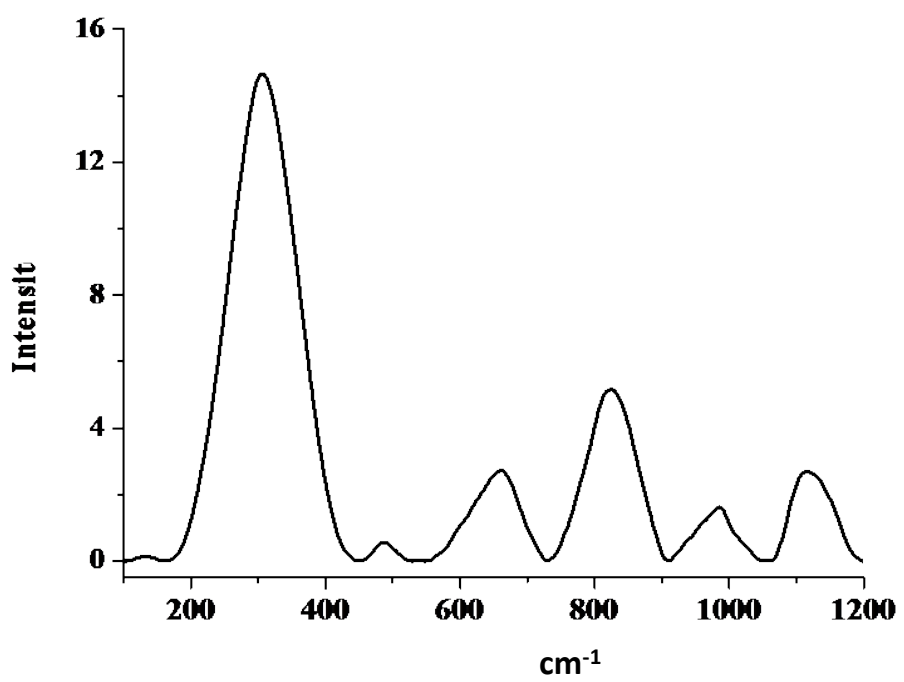

Figure 3. Raman spectroscopy of bauxite red mud from Ngaoundal. 


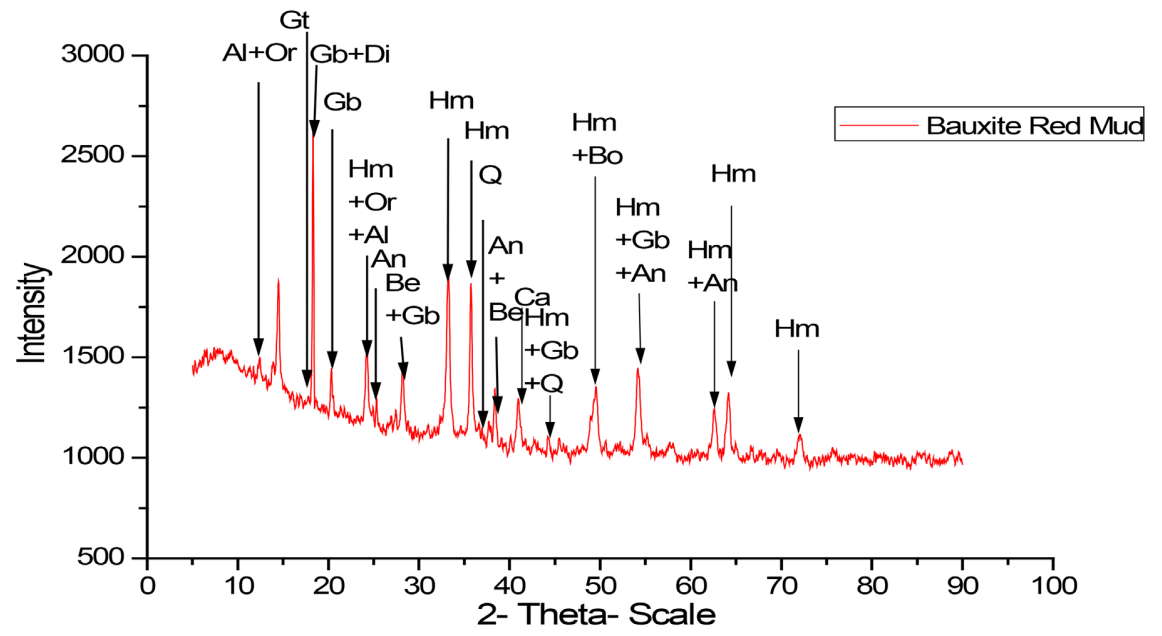

Figure 4. XRD pattern of red mud.

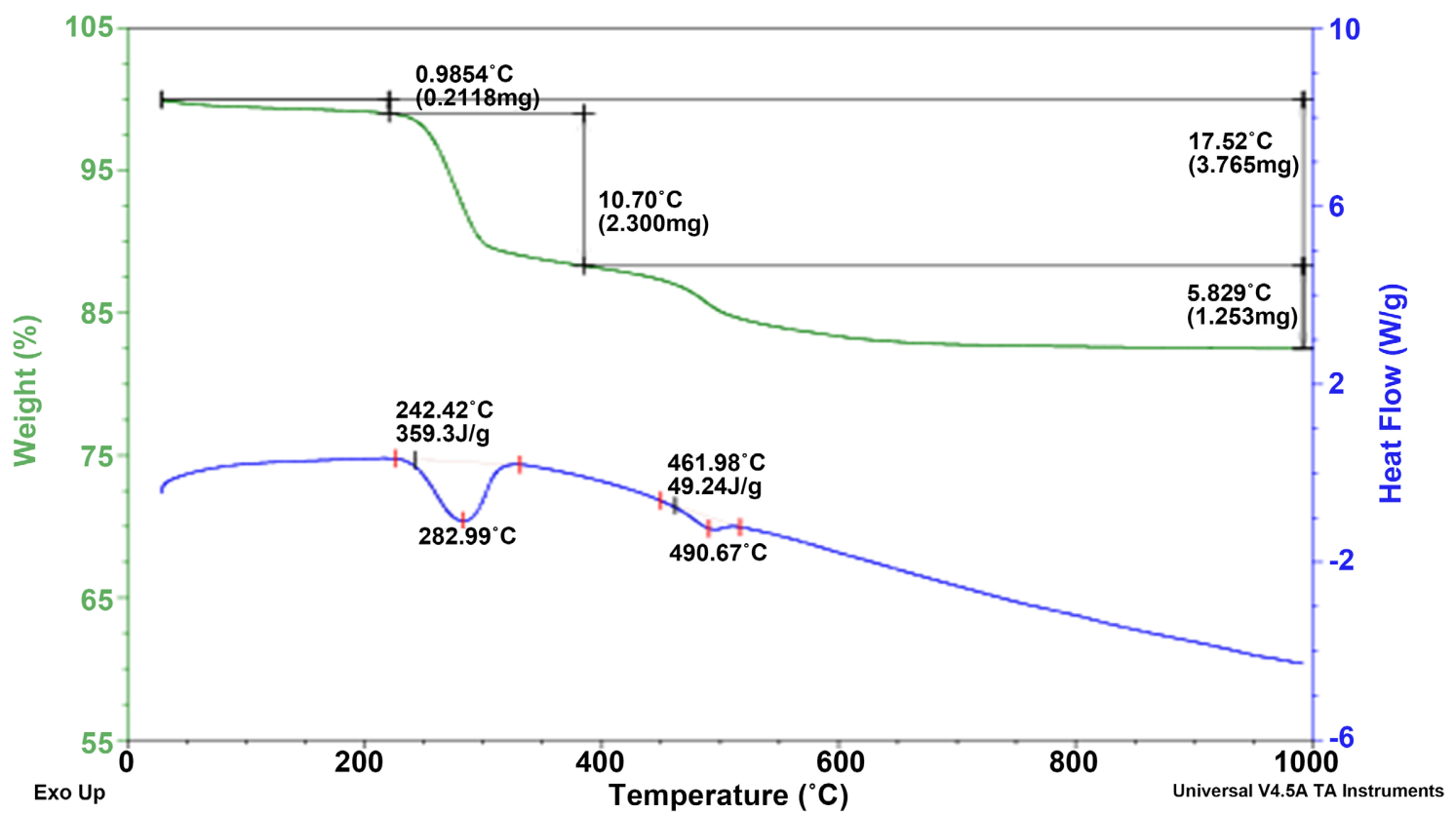

Figure 5. DSC-TGA curves of red mud (blue is DSC, green is TGA).

$$
2(\mathrm{OH})_{3} \cdot 2 \mathrm{H}_{2} \mathrm{O} \stackrel{282^{\circ} \mathrm{C}}{\longrightarrow} \mathrm{Al}_{2} \mathrm{O}_{3}+3 \mathrm{H}_{2} \mathrm{O}
$$

This dehydroxylation ends before $400^{\circ} \mathrm{C}$. According to the work of Kloprogge et al. [32] which showed that the maximum dehydroxylation temperature of gibbsite is around $300^{\circ} \mathrm{C}-310^{\circ} \mathrm{C}$ and that for crystallized gibbsites this value increases $\left(350^{\circ} \mathrm{C}-380^{\circ} \mathrm{C}\right)$. Thus we can deduce that the gibbsite contained in our material is crystallized. This endothermic peak around $282^{\circ} \mathrm{C}$ could also correspond to the dehydroxylation of lepidocrocite $(\gamma$-FeO $(\mathrm{OH}))$ according to the reaction Equation (1) [31];

$$
\begin{aligned}
& 2[\gamma-\mathrm{FeO}(\mathrm{OH})] \stackrel{282-300^{\circ} \mathrm{C}}{\longrightarrow} \gamma-\mathrm{Fe}_{2} \mathrm{O}_{3}+\mathrm{H}_{2} \mathrm{O} \\
& \text { Lepidocrocite maghémite eau }
\end{aligned}
$$


- There is a slight peak around $490^{\circ} \mathrm{C}$ corresponding to the dehydroxylation of boehmite [31] [33] [34] [35] according to the equation:

$$
\alpha-\mathrm{Al}_{2}(\mathrm{OOH})_{2} \stackrel{490^{\circ} \mathrm{C}}{\longrightarrow} \mathrm{Al}_{2} \mathrm{O}_{3}+\mathrm{H}_{2} \mathrm{O}
$$

The thermogravimetric curve of red bauxite sludge shows the following two thermal accidents:

- The first wave that starts around 25 and ends at $220^{\circ} \mathrm{C}$ with a mass loss of $0.98 \%$ or $0.2119 \mathrm{mg}$ the second wave starts 220 and ends at 390 and the maximum is $282^{\circ} \mathrm{C}$, and corresponds to the dehydroxylation of gibbsite to boehmite. This accident is accompanied by a loss of mass of approximately $10.70 \%$ or $2300 \mathrm{mg}$;

- The third wave, which starts at 400 and ends at $600^{\circ} \mathrm{C}$, is accompanied by a loss of mass of about $5.83 \%$ or $1.25 \mathrm{mg}$, and corresponds to the dehydroxylation of boehmite [34] [35]. In general, the ATG thermogram shows that throughout the analysis cycle, we observe a mass loss of 5.018 mg or a percentage of $23.35 \%$.

\subsection{Micro Morphological Characteristics}

Figure 4 shows that red mud are polycrystalline and poorly-crystallized or amorphous. The sample show more basic nature (white colouration) indicating higher surface area of contact with the base during extraction. This highly white colouration is expected as bauxite is digested in concentrated sodium hydroxide. The SEM image of red mud (Figure 6) are seen to have very low porosity and very crystalline structure, an indication that raw materials will produce a very homogenized Energy Dispersive of X-ray (EDX) analysis is used to determine the actual content of the red mud.

\subsection{Particle Size Distribution}

The computerized processing of the results made it possible to obtain the distribution of red bauxite sludge particles according to their occupied volumes. The software assimilates grains to spheres whose diameter values are plotted on the abscissa. The curve obtained (Figure 6) shows respectively the volumes occupied by each class of particles. We evaluated the maximum diameter corresponding to $10 \%\left(\mathrm{~d}_{10}\right), 50 \%\left(\mathrm{~d}_{50}\right)$ and $90 \%\left(\mathrm{~d}_{90}\right)$ of the cumulative volume of the particles. The results obtained are shown in Table 2 and Figure 7. The particle size distribution of a material is a very important physical property because it has an impact on the reactivity of the material and the product obtained after the veneering process, thus the finer the particles of a material, the greater the reactivity of this material.is high [34].

Table 2. Particles size of red mud.

\begin{tabular}{cccc}
\hline$\%$ & $\mathrm{D}_{10}$ & $\mathrm{D}_{50}$ & $\mathrm{D}_{90}$ \\
\hline Taille $(\mu \mathrm{m})$ & 1.641 & 14.341 & 62.458 \\
\hline
\end{tabular}



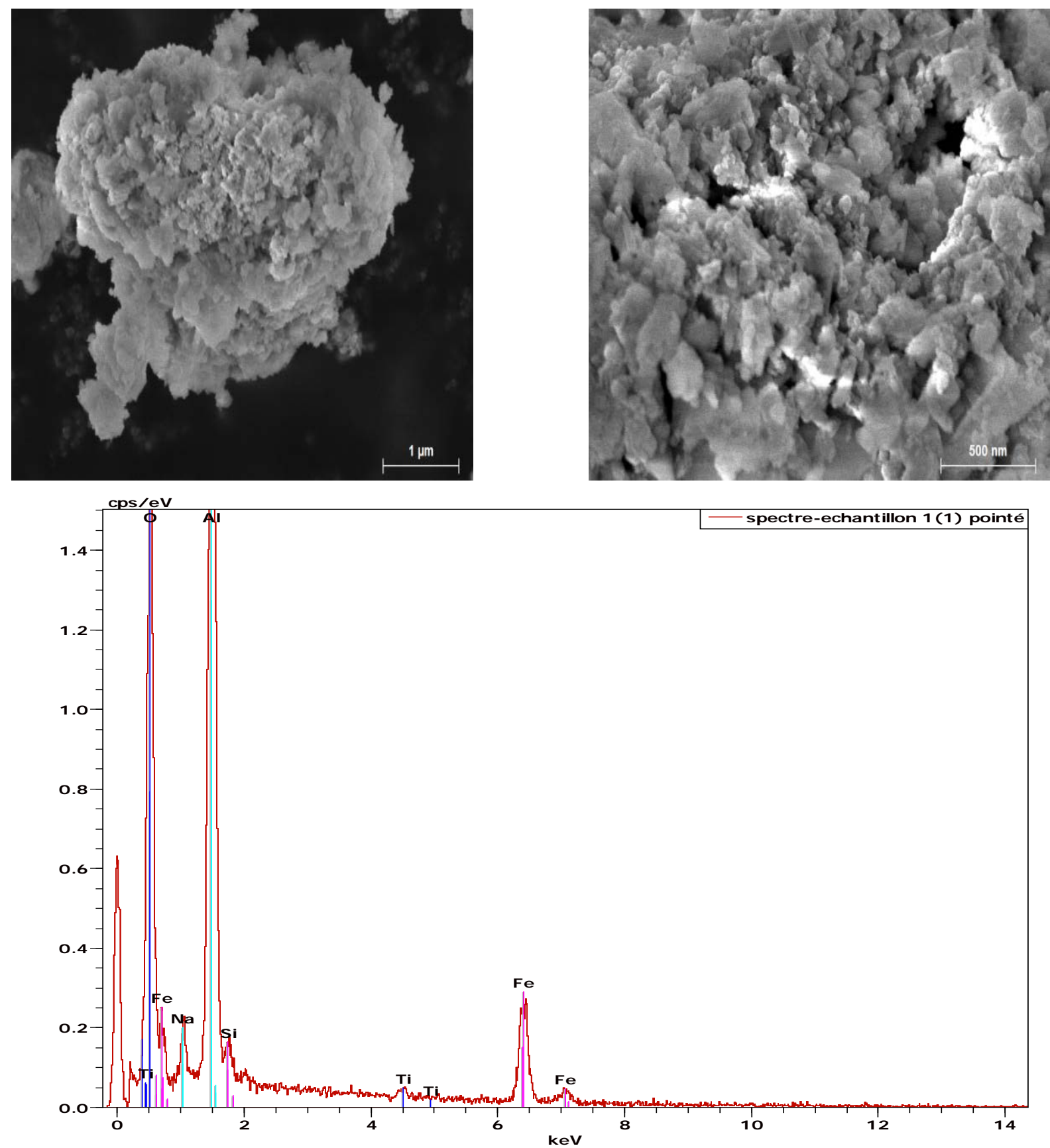

Figure 6. SEM images of red mud of Ngaoundal bauxite EDS spectra.

\section{Physicochemical and Technology Properties}

The physicochemical and technological results lead us towards semi-industrial applications for the manufacture of tiles, earthenware. According to the characteristic below, the manufacture of ceramic products is highly dependent on the quality of raw material. Baking temperature, linear shrinkage, fire loss, porosity and flexural strength are essential for judging ceramic product quality. Examining the results presented in Figure 7, it can be seen that: firing shrinkage, fire loss, porosity and flexural strength are variable as a function of temperature. 


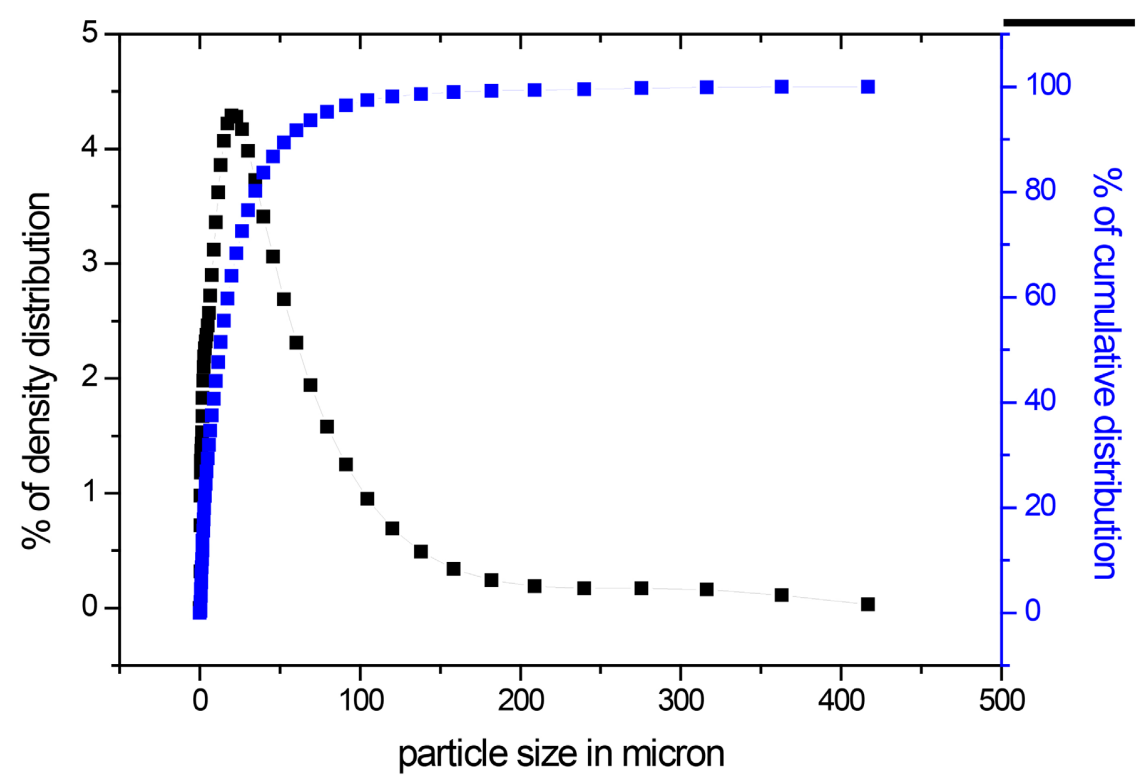

Figure 7. Particle size distribution of the red mud powder.

\subsection{Firing Shrinkage}

Shrinkage is related to the loss of water among red mud particles resulting in the closer packing of red mud particles. During firing, especially during sintering at high temperatures, ceramic particles fuse together leading to greater proximity and thus enhancing linear shrinkage. It is considered that the reduction in firing shrinkage of material had a positive impact. To minimize shrinkage, firing temperature which is an important parameter affecting the degree of shrinkage must be controlled during the firing process. The higher shrinkage could create problems as it may cause cracks and dimensional defects and this can contributed. The firing shrinkage increased with increasing firing temperature. Shrinkage is, normally, an important factor to determine the degree of densification during firing. Some bubbles that had been trapped in the specimens caused expansion. This phenomenon typically occurs during sintering of materials containing small amounts of water. The increasing of linear shrinkage is correlated to the good mechanical properties of a fired product.

Figure 8(A) show the evolution of Linear Shrinkage with firing temperature. These results are similar to those obtained by Ker Das et al. [35]. At $1000^{\circ} \mathrm{C}$, a linear shrinkage of $1.26 \%$ is observed. This is in agreement with the refractory behavior as confirmed by Djangang.

\subsection{Bulk Density}

As shown in Figure 8(B) the density of fired red mud its strength also increases, while its water absorption and apparent porosity decreases. The bulk density of fired red mud was proportional to the firing temperature. At higher temperatures, bloating presumably occurs having for effect to decrease the bulk density. The bulk density is related to durability and water absorption of red mud shape manufacture. 

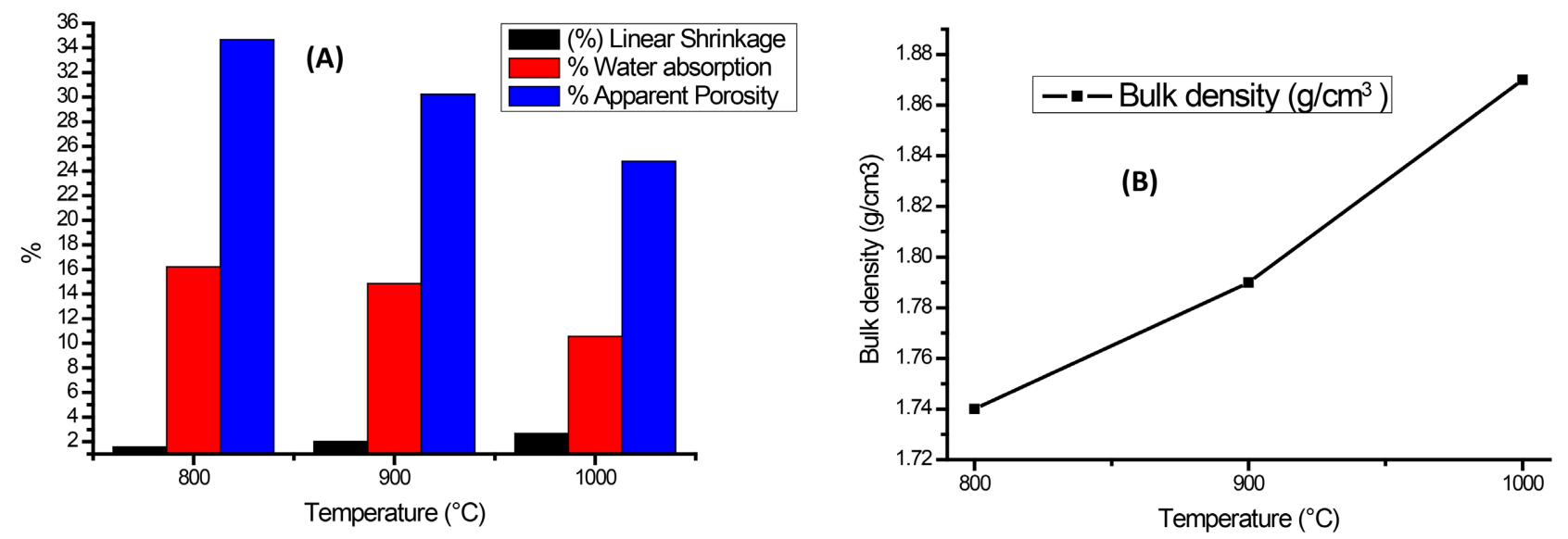

(C)

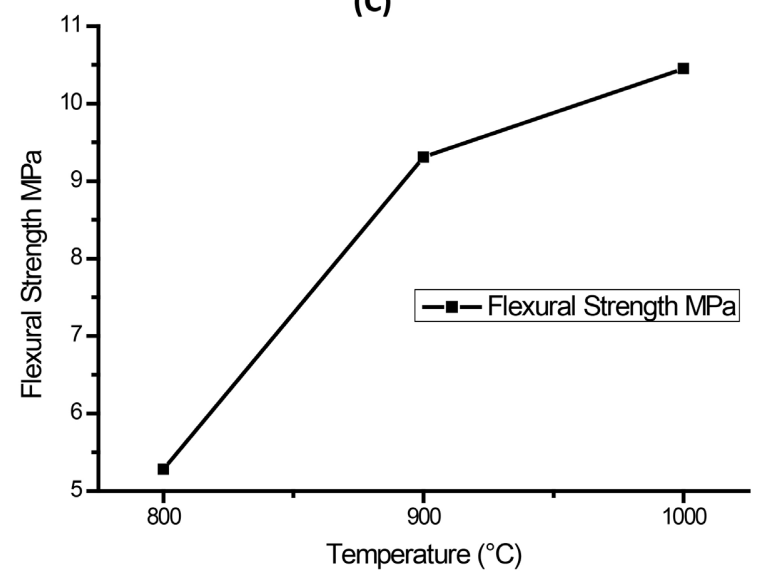

Figure 8. Influence of firing temperature. (A) Linear shrinkage, Water absorption and Apparent Porosity; (B) Bulk Density; (C) Flexural Strength.

\subsection{Water Absorption and Apparent Porosity}

As shown in Figure 8(C), when water infiltrates ceramic product, it decreases the durability. Thus, the internal structure of ceramic must be sufficiently dense to void the leaking of water. Figure 6(A) showed that the lowest water absorption value was obtained for fired at $1000^{\circ} \mathrm{C}$ which has the lowest porosity. The highest water absorption value was seen at $800^{\circ} \mathrm{C}$ which has the highest porosity. As understood here, there is a close relationship between water absorption and apparent porosity red mud fired. The reduction in both water absorption and apparent porosity after firing suggested the increase in the local liquid phase at high firing temperature, and thus contributed to a decrease in the pore volume.

\subsection{Appearance and Colour}

The chemical and mineralogical compositions of the red ceramic affect the firing color of the final product [26]. In the present study, after drying the samples different specimen no defects were observed. Cracks, bloating and other noticeable defects were not observed after firing. This means that drying process has well be done. Drying is the most important stage of the ceramic manufacturing process. Small cracks may develop during drying, causing a failure during firing [15] 
[32]. The color of final product was not changed after firing process. The visual observation for appearance and color of the ceramic bodies revealed that appearance and colors of ceramic bodies were acceptable. This variation may be due to the thermal reactions between several oxides contained into the raw materials mainly $\mathrm{Fe}_{2} \mathrm{O}_{3}$ and $\mathrm{TiO}_{2}$.

\subsection{Chemical Stability}

The analysis of Table 3 shows that the ions are weakly released in an acidic, basic and neutral medium. This low rate of salting out is observed due to the low variation of the conductivity of the tempering solution. But we note that after 8 days this value no longer changes. This reflects good chemical stability of ceramics in an acidic and basic medium. Table 4 confirms the resistance to corrosion in an acid-base medium.

According to the results obtained by the corrosion test (Table 4), the weight loss was proportional to the reaction time. The weight loss also varied with the reaction medium (acidic or basic). The highest corrosion rate $(0.85 \%)$ was obtained after a basic attack after 30 days of impregnation; this is due to the large proportion of quartz $\left(\mathrm{SiO}_{2}\right)$, which was acidic and therefore easily reacted in a basic medium. The lowest corrosion rate (0.19\%). Analysis of the results showed that despite the nature of the red bauxite mud used, the samples had low porosity

Table 3. Influence of conductivity at given $\mathrm{PH}$ in function of soaking time.

\begin{tabular}{cccccccc}
\hline Day & 1 & 2 & 4 & 6 & 8 & 10 & 30 \\
\hline Cond $(\mu \mathrm{S} / \mathrm{cm})$ at & & & & PH 3.98 & & & \\
$\mathbf{8 0 0} \mathrm{C}$ & 150 & 157 & 159 & 157 & 155 & 155 & 155 \\
$\mathbf{9 0 0 ^ { \circ } \mathrm { C }}$ & 150 & 143 & 153 & 152 & 152 & 152 & 152 \\
$\mathbf{1 0 0 0 ^ { \circ } \mathrm { C }}$ & 150 & 150 & 150 & 152 & 152 & 152 & 152 \\
\hline & & & & $\mathrm{PH} 6.74$ & & & \\
$\mathbf{8 0 0 ^ { \circ } \mathrm { C }}$ & 5 & 5.1 & 5.3 & 5.3 & 5.6 & 6.07 & 6.67 \\
$\mathbf{9 0 0 ^ { \circ } \mathrm { C }}$ & 5 & 5.01 & 5.21 & 5.41 & 5.79 & 5.81 & 5.81 \\
$\mathbf{1 0 0 0 ^ { \circ } \mathrm { C }}$ & 5 & 5.03 & 5.09 & 5.13 & 5.17 & 5.22 & 5.23 \\
\hline & & & & $\mathrm{PH} \mathrm{9.05}$ & & & \\
$\mathbf{8 0 0 ^ { \circ } \mathrm { C }}$ & 1000 & 1003 & 1013 & 1008 & 1007 & 1007 & 1008 \\
$\mathbf{9 0 0 ^ { \circ } \mathrm { C }}$ & 1000 & 1000 & 1001 & 1001 & 1002 & 1002 & 1008 \\
$\mathbf{1 0 0 0 ^ { \circ } \mathrm { C }}$ & 1000 & 1043 & 1057 & 1023 & 1012 & 1007 & 1007 \\
\hline
\end{tabular}

Table 4. Weight loss in sulphuric acid $(\mathrm{pH}=1.68)$ and soda solution $(\mathrm{pH}=13.24)$ as a function of time at $105^{\circ} \mathrm{C}$.

\begin{tabular}{lcccccccccc}
\hline & Time (D) & $\mathbf{0 . 2 5}$ & $\mathbf{0 . 5}$ & $\mathbf{1}$ & $\mathbf{2}$ & $\mathbf{4}$ & $\mathbf{6}$ & $\mathbf{8}$ & $\mathbf{1 0}$ & $\mathbf{3 0}$ \\
\hline $\begin{array}{l}\text { Weight } \\
\text { loss \% }\end{array}$ & $\mathrm{NaOH}$ & 0 & 0.19 & 0.20 & 0.24 & 0.26 & 0.38 & 0.38 & 0.38 & 0.40 \\
& $\mathrm{H}_{2} \mathrm{SO}_{4}$ & 0 & 0.21 & 0.28 & 0.57 & 0.57 & $0 / 72$ & 0.84 & 0.84 & 0.85 \\
\hline
\end{tabular}


hence the low corrosion values of the specimens. Rekik et al. [15] and Djonga et al. [13] obtained a chemical resistance of $6 \%$ after acid and basic attacks at different temperatures and average concentrations. A treatment should be done to reduce or even eradicate the loss of mass and reduce the corrosion problem that the materials undergoes. Taking into account the results obtained by these authors, it can be said that the stoneware or ceramic tiles developed in the present work have a high resistance to chemical corrosion and can be used in acidic and basic environments.

\section{Microstructural Analysis and Mineralogical Composition}

The SEM micrograph of tile specimens fired at $1000^{\circ} \mathrm{C}$ is depicted by Figure 9. Image point out that microstructure of the tile body is not thoroughly homogeneous (Table 5). Ceramics show large amount of liquid phase formed, this implies the lower porosity and better densification during firing process. The presence of carbon would probably be due to the decomposition of the carbonate with release of carbon dioxide in the material during the sintering process.

Figure 10 shows the diffraction patterns of the tiles specimens fired at $1000^{\circ} \mathrm{C}$ for $2 \mathrm{~h}$. The crystalline phases identified in samples fired are quartz, Hematite, Cristobalite, Aluminum Oxide, Orthoclase and Iron Phosphate. The formation of these new phases combined to those already existing, is an advantage for sintered glass composite since they display the mechanical improvement.

Table 5. Elementary composition of sintered ceramic at $1000^{\circ} \mathrm{C}$.

\begin{tabular}{cccccccccc}
\hline Spectrum & $\mathrm{C}$ & $\mathrm{O}$ & $\mathrm{Na}$ & $\mathrm{Al}$ & $\mathrm{Si}$ & $\mathrm{K}$ & $\mathrm{Ti}$ & $\mathrm{Fe}$ & Total \\
\hline Spectrum 1 & 10.32 & 49.56 & 0.96 & 14.03 & 7.78 & 0.93 & 2.24 & 14.17 & 100 \\
Spectrum 2 & 16.72 & 50.41 & 1.57 & 9.38 & 12.73 & 1.42 & 1.13 & 6.64 & 100 \\
Spectrum 3 & 16.25 & 50.06 & 1.62 & 9.76 & 13.45 & 1.57 & 1.13 & 6.16 & 100 \\
Spectrum 4 & 28.55 & 46.93 & 1.06 & 7.17 & 9.64 & 1.23 & 0.8 & 4.63 & 100 \\
Spectrum 5 & 11.2 & 52.43 & 1.74 & 10.26 & 14.07 & 1.57 & 1.16 & 7.57 & 100 \\
Mean & 16.61 & $\mathbf{4 9 . 8 8}$ & $\mathbf{1 . 3 9}$ & $\mathbf{1 0 . 1 2}$ & $\mathbf{1 1 . 5 3}$ & $\mathbf{1 . 3 4}$ & $\mathbf{1 . 2 9}$ & $\mathbf{7 . 8 4}$ & 100 \\
\hline
\end{tabular}
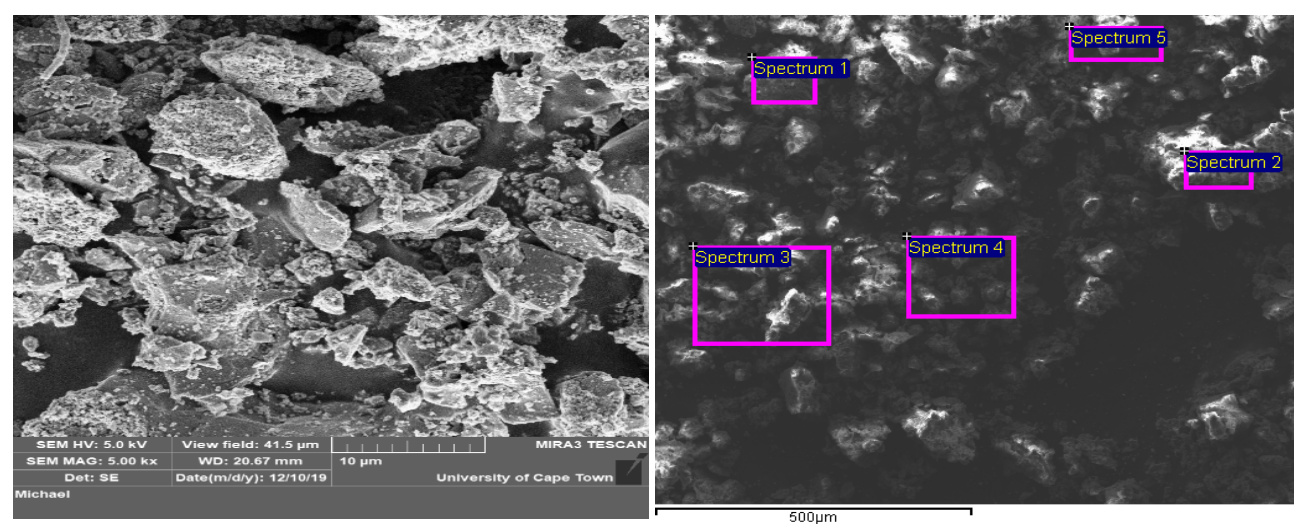

Figure 9. SEM and EDS of fired product at $1000^{\circ} \mathrm{C}$. 


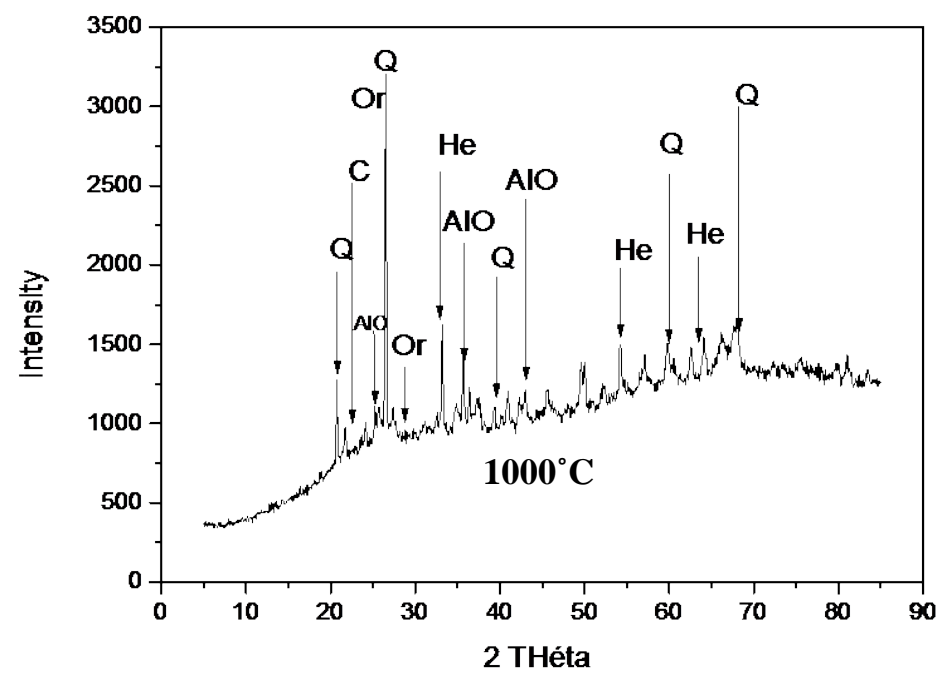

He: Hematite $\left(\mathrm{Fe}_{2} \mathrm{O}_{3}\right)=36.45 \%$;

Q: Quartz $\left(\mathrm{SiO}_{2}\right)=20.59 \%$

Cr: Cristobalite $\left(\mathrm{SiO}_{2}\right)=10.42 \%$;

AlO: Aluminum Oxide $\left(\mathrm{Al}_{2} \mathrm{O}_{3}\right)=10.43 \%$

Or: Orthoclase $\left(\mathrm{KAlSi}_{3} \mathrm{O}_{8}\right)=6.25 \%$;

IP: Iron Phosphate $\left(\mathrm{FePO}_{4}\right)=16.67 \%$

Figure 10. DRX of ceramic made from bauxite red mud fired at $1000^{\circ} \mathrm{C}$.

\section{Conclusion}

Results of this work point out the possibility of using red mud as raw material for roof tile. XRF, XRD and IR revealed components which give the possibility to enhance the quality of manufactured ceramic. Physical and mechanical tests were performed to investigate that temperature of firing specimen has a significance effect on the properties such as Linear Shrinkage, Flexural strength, Water absorption, apparent porosity and bulk density. Linear Shrinkage (0.59 to $1.28 \%$ ), Flexural strength (5.28 to $10.45 \mathrm{MPa}$ ), Water absorption (16.23 to $12.56 \%$ ), and Apparent Porosity (34.68 to $24.80 \%$ ) vary with increasing temperature. The good properties are obtained when high firing temperature such as $1000^{\circ} \mathrm{C}$. Analysis of results obtained showed that waste material red mud firing at $1000^{\circ} \mathrm{C}$ can be used in roof tile manufacture, also the use of this waste could be beneficial for sustainable development of the environment.

\section{Declaration of Competing Interest}

The authors declare that they have no known competing financial interests or personal relationships that could appeared to influence the work reported in this paper.

\section{Acknowledgements}

This research did not receive any specific grant from funding agencies in the public, commercial, or non-profit sectors. Additionally, the first author gratefully acknowledges Dr. Remy in iThemba LABS-National Research Foundation for XRD analyse.

\section{Conflicts of Interest}

The authors declare no conflicts of interest regarding the publication of this paper. 


\section{References}

[1] Venkatesh, C., Rama, M.S. and Nerella, R. (2019) A State of the Art on Red Mud as a Substitutional Cementitious Material. Annales de Chimie: Science des Matériaux, 43, 99-106. https://doi.org/10.18280/acsm.430206

[2] Khairul, M.A., Zanganeh, J. and Moghtaderi, B. (2019) The Composition, Recycling and Utilisation of Bayer Red Mud. Resources Conservation and Recycling, 141, 483-498. https://doi.org/10.1016/j.resconrec.2018.11.006

[3] Alam, S., Das, S.K. and Rao, B.H. (2019) Strength and Durability Characteristic of Alkali Activated GGBS Stabilized Red Mud as Geo-Material. Construction and Building Materials, 211, 932-942. https://doi.org/10.1016/j.conbuildmat.2019.03.261

[4] Ortega, J.M., Cabeza, M., Abril, T., Real, A.J., Climent, T. and Sánchez, M.A. (2019) Effects of Red Mud Addition in the Microstructure, Durability and Mechanical Performance of Cement Mortars. Applied Sciences, 9, Article No. 984. https://doi.org/10.3390/app9050984

[5] Qu, Y., Li, H., Wang, X., Tian, W., Shi, B., Yao, M. and Zhang, Y. (2019) Bioleaching of Major, Rare Earth, and Radioactive Elements from Red Mud by using Indigenous Chemoheterotrophic Bacterium Acetobacter sp. Minerals, 9, Article No. 67. https://doi.org/10.3390/min9020067

[6] Samal, S., Ray, K. and Bandopadhyay, A. (2013) Proposal for Resources, Utilization and Processes of rEd Mud in India-A Review. International Journal of Mineral Processing, 118, 43-55. https://doi.org/10.1016/j.minpro.2012.11.001

[7] Cornelius, T. and Kamga, R. (2017) Variation of Physico-Chemical and Textural Properties of Laboratory Prepared Red Mud through Acid and Thermal Activations. Advances in Materials, 6, 11-19. https://doi.org/10.11648/j.am.20170602.12

[8] Wang, H.M. and Tadé, M.O. (2008) Novel Applications of Red Mud as Coagulant, Adsorbent and Catalyst for Environmentally Benign Processes. Chemosphere, 72, 1621-1635. https://doi.org/10.1016/j.chemosphere.2008.05.013

[9] Kumar, S., Kumar, R. and Bandopadhyay, A. (2006) Innovative Methodologies for the Utilisation of Wastes from Metallurgical and Allied Industries. Resources, Conservation and Recycling, 48, 301-314. https://doi.org/10.1016/j.resconrec.2006.03.003

[10] Wu, C.-S. and Liu, D.-Y. (2012) Mineral Phase and Physical Properties of Red Mud Calcined at Different Temperatures. Journal of Nanomaterials, 2012, Article ID: 628592, 6 p. https://doi.org/10.1155/2012/628592

[11] Ze, P.A., Tsamo, C. and Kamga, R. (2018) Characterization of Minim-Martap Bauxite and Its Extracted Alumina. Journal of Advanced Chemical Sciences, 4, 598-600.

[12] Tsamo, C., Djomou Djonga, P.N., Dangwang Dikdim, J.M. and Kamga, R. (2017) Kinetic and Equilibrium Studies of $\mathrm{Cr}(\mathrm{VI}), \mathrm{Cu}(\mathrm{II})$ and $\mathrm{Pb}(\mathrm{II})$ Removal from Aqueous Solution Using Red Mud, a Low-Cost Adsorbent. Arabian Journal for Science and Engineering, 43, 2353-2368. https://doi.org/10.1007/s13369-017-2787-5

[13] Djonga, P.N.D., Tsamo, C. and Massai, H. (2019) Influence of CRT Glass Quantity on the Properties of Red Mud-CRT Glass Ceramics Fired at Different Temperatures. Journal of Materials Science and Engineering B, 9, 133-143. https://doi.org/10.17265/2161-6221/2019.7-8.002

[14] Souaibou, Antoine, E. and Raidandi, D. (2019) Influence of the Colorless Waste Glass on the Mineralogical, Microstructural and Mechanical Properties of Clay Material from Wack (Adamawa, Cameroon). Advances in Materials Physics and Chemistry, 9, 89-102. https://doi.org/10.4236/ampc.2019.95008 
[15] Tiffo, E., Elimbi, A., Dika, M.J. and Tchamba, A.B. (2015) Red Ceramics Produced from Mixtures of Kaolinite Clay and Waste Glass. Brazilian Journal of Sciences \& Technology, 2, Article No. 4. https://doi.org/10.1186/s40552-015-0009-9

[16] ASTM International (2014) ASTM C326-09. Standard Test Method for Drying and Firing Shrinkages of Ceramic Whiteware Clays. ASTM Book of Standards, West Conshohocken.

[17] ASTM International (2006) ASTM C373-88. Standard Test Method for Water Absorption, Bulk Density, Apparent Porosity, and Apparent Specific Gravity of Fired Whiteware Products, Ceramic Tiles, and Glass Tiles. ASTM Book of Standards, West Conshohocken.

[18] Fragassa, C. (2015) Limits in Application of International Standards to Innovative Solutions. International Journal for Quality Research, 9, 279-298.

[19] ASTM International (1997) ASTM C 674-77. Standard Test Method for Flexural Properties of Ceramic Whiteware Materials.

[20] Grafe, M. and Power, G. (2009) Review of Bauxite Residue Alkalinity and Associated Chemistry. CSIRO Document DMR-3610.

[21] Bianchini, G., Laviano, R., Lovo, S. and Vaccaro, C. (2002) Chemical-Mineralogical Characterisation of Clay Sediments around Ferrara (Italy): A Tool for an Environmental Analysis. Applied Clay Science, 21, 165-176.

https://doi.org/10.1016/S0169-1317(01)00086-2

[22] Kloprogge, J.T., Ruan, H.D., Frost, R.L. (2002) Thermal Decomposition of Bauxite Minerals: Infrared Emission Spectroscopy of Gibbsite, Boehmite and Diaspore. Journal of Materials Science, 37, 1121-1129. https://doi.org/10.1023/A:1014303119055

[23] Tchamba, A.B., Yongue, R., Melo, U.C., Kamseu, E., Njoya, D. and Njopwouo (2008) Caracte risation de la bauxite de Hale o-Danielle (Minim-Martap, Cameroun) en vue de son utilisation industrielle dans les mate riaux a haute teneur en alumine. Silicates Industriels, 73, 77-83.

[24] Mistry, B.D. (2009) A Handbook of Spectroscopic Data Chemistry (UV, JR, PMR, JJCNMR and Mass Spectroscopy). Oxford Book Company, Jaipur.

[25] Atchana, J., DjomouDjonga, P.N., Loura, B., Hambate, V.G. and Tchatchueng, J.B. (2021) Elaboration of Porous Geopolymer Cement from Sangaré Clay and Shell Egg Powder: Application as Thermal Insulation. American Journal of Materials Engineering and Technology, 9, 21-30.

[26] Djonga, P.N.D., Tsamo, C. and Massai, H. (year) Effect of Temperature on Mechanical and Chemical Properties of Fired Ceramic Produced from Cathode-Ray Tube (CRT) Waste Glass and Red Mud Bauxite from Ngaoundal (Cameroon).

[27] Rollet, A.-P. and Bouaziz R., (1972). L'analyse Thermique: L'examen des processus chimique, tome 2, GAUTHIER-VILLAS, Paris, $571 \mathrm{p}$.

[28] Yusiharni, E. and Gilkes, R. (2012) Rehydration of Heated Gibbsite, Kaolinite and Goethite: An Assessment of Properties and Environmental Significance. Applied Clay Science, 64, 61-74. https://doi.org/10.1016/j.clay.2011.12.005

[29] Diaz, E.I., Allouche, E.N., Eklund, S. (2010) Factors Affecting the Suitability of Fly Ash as Source material for Geopolymers. Fuel, 89, 992-996. https://doi.org/10.1016/j.fuel.2009.09.012

[30] Das, S.K., Dana, K., Singh, N. and Sarkar, R. (2005) Shrinkage and Strength Behaviour of Quartzitic and Kaolinitic Clays in Wall Tile Compositions. Applied Clay Science, 29, 137-143. https://doi.org/10.1016/j.clay.2004.10.002 
[31] Djomou Djonga, P.N., Atchana, J., Gomdje Hambate, V., Yohana, Y.N. and Tchuidjan Tchamba, T. (2021) Physico Chemical Properties of Sangaré-Clay in the Traditional Ceramic Industry and Properties of Building Brick: Influence of Temperature on Mechanical Properties of Fired Product. International Journal of Engineering Technology and Scientific Innovation, 6.

https://doi.org/10.51193/IJETSI.2021.6101

[32] Carretero, M.I., Dondi, M., Fabri, M., Raimondo, M. (2002) The Influence of Shaping and Firing Technology on Ceramic Properties of Calcareous and Non-Calcareous Illitic-Chloritic Clays. Applied Clay Science, 20, 301-306.

https://doi.org/10.1016/S0169-1317(01)00076-X

[33] Correi, S.L., Hotza, D. and Segadae, S.A. (2004) Simultaneous Optimization of Linear Firing Shrinkage and Water Absorption of Triaxial Ceramic Bodies Using Experiments Design. Ceramics International, 30, 917-922.

https://doi.org/10.1016/j.ceramint.2003.10.013

[34] Oliveira, G.E. and Holanda, J.N.F. (2004) Use of Mix of Clay/Solid Waste from Steel Works for Civil Construction Materials. Waste Management \& Research, 22, 358-363. https://doi.org/10.1177/0734242X04047209

[35] Demir, I. (2008) Effect of Organic Residues Addition on the Technological Properties of Clay Bricks. Waste Management, 28, 622-627.

https://doi.org/10.1016/j.wasman.2007.03.019 